Historic, archived document

Do not assume content reflects current scientific knowledge, policies, or practices. 



\title{
DESCRIPTIVE GIRCULAR
}

\author{
OF \\ Chatice Seed Pats, \\ GROWN AND FOR SALE BY \\ Edward E. Evans \& Co. \\ NURSER YMEN ALD SEEDSMEN, \\ YORR, P E M N P .
}

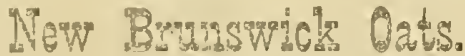

"This exceedingly valuible new Oats was obtained a few years ago from the British Provine of Jew Brunswiek (whence its name), and

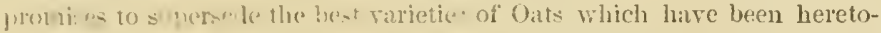

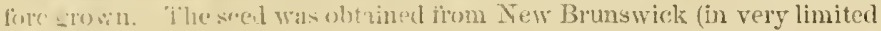
gentity? lw Mr. Watson Vewbold, of New Jersey, one of the most in-

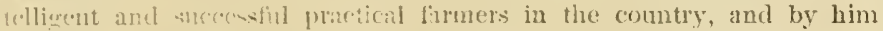

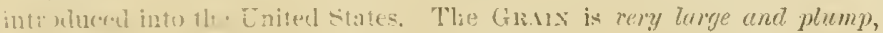

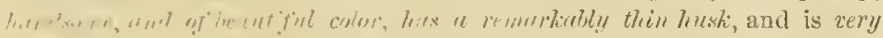

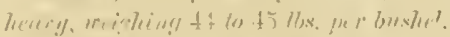

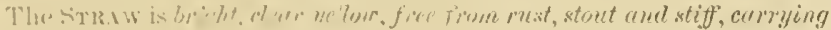

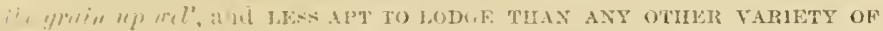

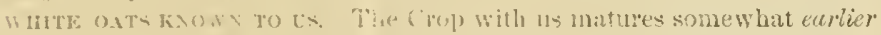

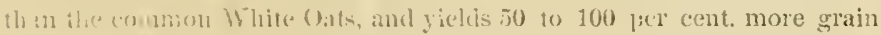
ber ac\% on the sam solit, and with the same enlture.

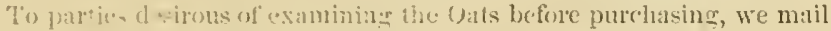

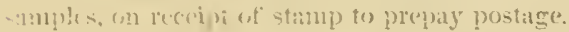

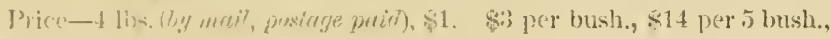
(sar in includ il.

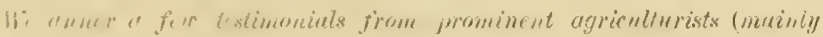

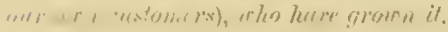

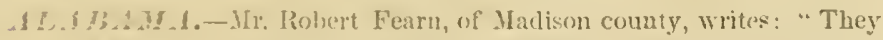
(ai: 111 ) w (7) is lnown in this section, and maintained it thromglont the entire :aison. Yiuhl not known, but enough to satisfy eren an unrersomble 
NORTIT CAROLIXA.-Thos. A. Iatliffe, of Roekingliam county, Writes: "()f the 2 bushels 1 purehased of you, they were distributed anong several fumers for experimenting, and the report firou all is geod. I sowed about half a lushel at the same time of sowiug the common Oats; they grew off much more luxuriantly, with more stalk and fodder, grew ahout ( $\mathrm{inches}$ higher, and ripened 20 days earlier, sille hy side, with other White Oats. They are much heavier than the Oats we liave been growing in N. C."

Mr. A. W. Alexinder, of Mechlenburg county, writes: "I eonsider throm a hetter Oits than any we have. Notwithstanding they were sowerl late, they wore the first to ripen. I am pleased with them and will try them agrain."

SEW IORK.-Mr. Aaron Bratt, of Saratoga eounty, writes: "The sample that you sent me last Winter have grown five feet six inehes hight, and are very nice Oats; they yielded at the rate of one hundred bushels to the acre."

Mr. W. Hollis, Jr, of Clenango eounty, writes: "They will average from 12 to 20 inclaes higher than common Oats, on the same quality of soil, and promise a good yield. I think they were the best Oats I rver saw growing."

TEM IERSE 1.-Mr. Newbrlal (the introlueer), in speaking of it in 186.), says: "I have for yours endeavored to proeure some of the very best and beaviest Oilk grown in America, but did not sueeed to my satisfirtion until I obtained these, and eould only get a limited quantity, as they had to be transported on lorseback a very long distauce, from the interior to mavigation. These Oats will show for themselves, and need only to be seen to eonrince any oue of their superior expellence, being plump, with a large full wain, insicte a thin husk; weigh 4:3 liss. pel bushel, and are the best Oats I ever knew grown in the Unuted States." In February, 1567, he writes us, "It has maintained its superiority beyone? my expeetation, as all extra Oats are considered to depreciate in this latitude, more or less."

PENXSIEIANIA.-C'aschall Mortis, Esq., of Philadelphia (excellent authority on the suhjeet), in noticing a sample of it in 186\%, wrote: "It exceeds in weight, hrightuess, and general appearance, nuything we have ever seen of the Oat finnily. The Oat erop has been mueh of a failure for the few last years, and as this seed from aunther climate and soil has proved by the past year's growth liere to protuee well, it will probably prove a valuable acquisition."

Mr. D. II. liranson, of Chesier county, Pa., states in Precticul Farmer for Noy," 186\%: "Laving purchased, in the Spring of ' 66 , two bushels of the above-nanted Oilts, and grown it with suel astonishing success for two successive seasons, without the slightest deterioration, I will brietly stutr my experiener rolative to its qualities. The two hushels above mentioned were sown in dyill, on three-quarters of an aere, the i0th day of' $A$ pril, ' 66 . The yield was 41 bushels, weighing 40 lbs. by 


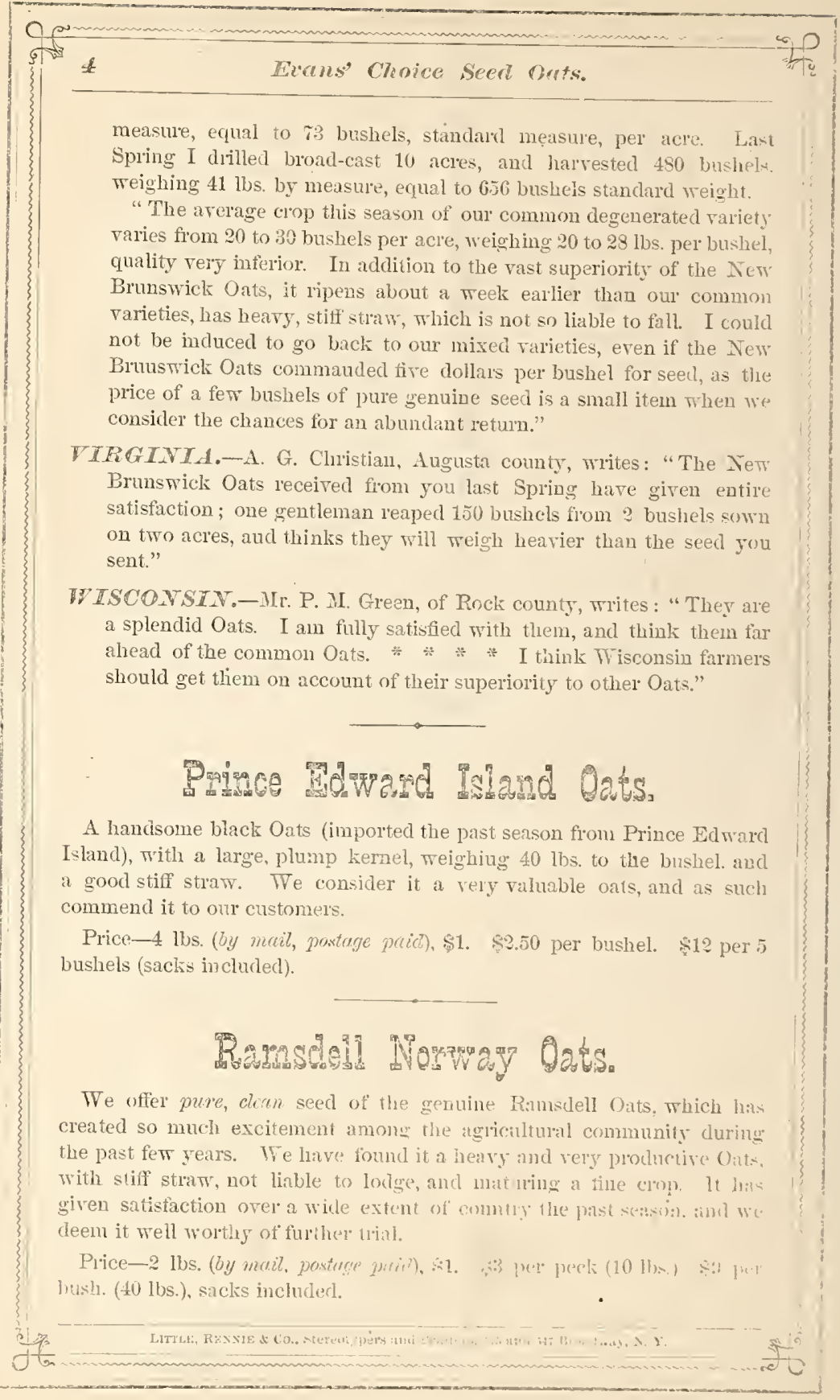

